\title{
ALTERNATIVE TOOLS FOR MOTIVATING YOUNG PRIMARY SCHOOL STUDENTS WHEN LEARNING MATHS
}

\author{
Lidija Vinkler \\ Primary school Cerklje ob Krki, Slovenia \\ lidija.novak80@gmail.com
}

\section{Professional Paper \\ 10.5937/jouproman8-29210}

\begin{abstract}
A decrease in concentration, motivation and academic success is a common occurrence with elementary school pupils. This is most noticeable in STEM lessons, particularly in Maths. Teachers resort to various teaching approaches in order to motivate students. However, teachers often realize such approaches bring no significant success in the classroom due to a lack of interest on the part of the students. The motivation and success of students can be increased by grouping the students within heterogeneous classes, which is frequently used with younger elementary school students.

The article features a description of three different activities, which can be used to make Maths lessons more appealing when given to students in groups. At first, the activities might not seem related to Maths, but try them as they are great examples of activities, which increase mathematical thought. Described activities are Mud Town, Map Colouring and Ice Cream Stands.
\end{abstract}

Key words: didactic approaches, grouping pupils, heterogeneous class, Ice cream Stands, Map Colouring, mathematic class, motivation, Mud Town.

\section{Introduction}

In the article, we explain the use of graph theory in smaller groups of primary school students when teaching Maths. The main idea underlying the method of organizing children into groups based on their individual abilities is learning process optimization. Such teaching method is necessary for a more efficient time use when organizing and self-regulating the learning process in a way that leaves more room for teaching itself. This means more time to answer the students' questions, more explanation, more active listening, a quicker response to the classroom dynamic and more time to monitor individuals' progress within the group.

This, however, requires more interaction between the teacher and the student which is possible when the teacher communicates with groups of students rather than individual students. Namely, Žagar (2003) explains that dealing with too heterogeneous groups can reduce the time the students have to complete their tasks, consequently resulting in poorer achievements. Using problem oriented activities in connection with graph theory, however, can increase the success in solving traditional mathematical tasks. We proceed to explain how grouping students and using well-thought activities can increase the motivation of young learners in Maths lessons.

\section{Grouping the students}

In classes, the students can be grouped differently, depending on the criteria and the desired outcome of group work (Adamič, 1996). 
Hollifield (1987) explains, that when forming homogenous groups, our aim is to put students into groups according to their achievements in standardized abilities tests in one self-contained class. Usually, the students are divided into three levels, i. e. high, average and low. Such formulation of groups requires teaching at different levels which are customized to the abilities of the students and is used at all or most subjects. Hollifield (1987), however, explains that such settings do not improve student achievement.

Another way of grouping the students is assigning students to heterogeneous classes for most of the day, but regrouping them in particular settings in one or more subjects according to their achievements. Such form of grouping can enhance student achievement, but only when the level and the pace of instruction are adapted to the students' abilities (Hollifield, 1987).

A grouping plan that has shown success in improving the students' reading abilities is the Joplin Plan which suggests putting students in heterogeneous classes for most of the day and regrouping them for reading instruction. For example, a reading class at the fifth grade, first semester level might include high achieving fourth graders, average achieving fifth graders, and low achieving sixth graders (Hollifield, 1987).

Lastly, we should mention within-class ability grouping which is frequently used for reading or mathematics. The students are assigned to one or more groups within their class according to their abilities. This allows for individual group to work at its own pace. These groups work on different materials at rates unique to their needs and abilities. The positive effects are slightly greater for low-achieving students than for average or high achievers (Hollifield, 1987).
Slavin's meta-analytical study (Slavin, 1989) of student grouping exposes the following key findings:

- Assumed negative psychological effects of grouping are not significant,

- Ability-based groups are formed according to the students' achievements in reading or maths,

- Ability-based groups are flexible, making it relatively simple for the students to switch groups.

Slavin concluded that studies support the effectiveness of ability-based groups in particular subjects only if the teaching methods and materials are suited to the students' needs. Žagar (2003) concludes that based on relevant literature, the most suitable form of grouping younger primary school students is within-class grouping, as it heterogeneous classrooms while taking into account individuals' needs, interests and abilities.

\section{Examples of graph-theory based tasks suited for group work at Maths lessons}

In order to improve students' motivation in Maths lessons, we suggest the use of graph theory based tasks, while keeping the students in smaller within-class groups based on their abilities. In this particular case, working in groups can give students opportunity to find the solution at their own pace, rather than be shut down by those students, who are quicker and giving the answers. By using interesting, storytelling tasks, we show the students that mathematics is fun and full of activity and that it is a live science with visible frontiers of knowledge (Fellows, 1993). We present three individual tasks below. 


\section{The Mud Town}

We introduce the students with the problem of Mud Town. The residents of the Mud Town wish to pave so many roads, that every resident could travel anywhere. They also want to keep the costs as low as possible, even if this makes travelling on the paved roads longer. Mathematically speaking, we wish to calculate the smallest number of connections, i. e. paved roads, between each point.

Picture 1: The Mud Town (personal archive)

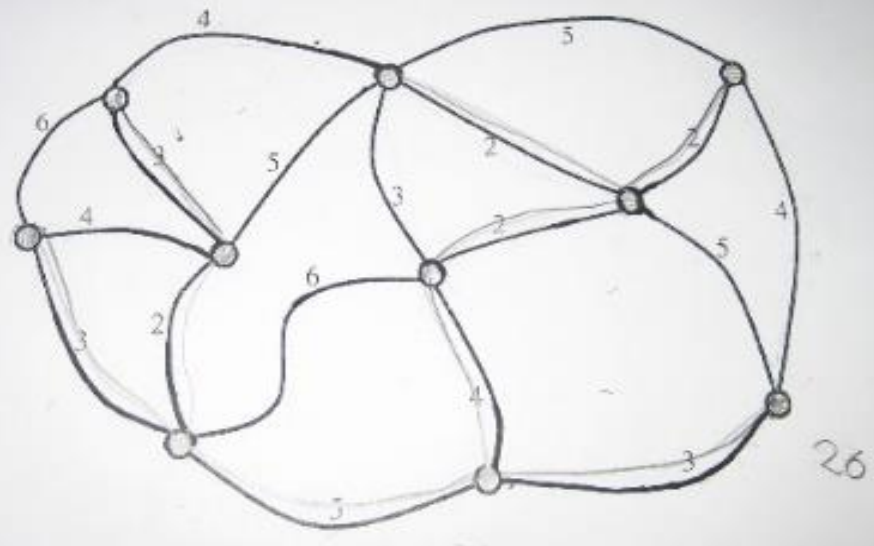

The use of various algorithms would be helpful in solving the above task, however, they are not appropriate for younger primary school students. We begin by placing the map of the Mud Town before the students (Picture 1). We explain the problems the residents encounter daily: their shoes are dirty, their cars keep getting stuck in mud, etc. The mayor insists that some roads must be paved. He wants to pave so many roads, that every resident can travel from their home to any other home in the town. However, the paving has to be done at a minimal cost which will leave more money for a brand new swimming pool. The number along each road equals to the cost of paving that particular part of the road. Therefore, the cost of paving all the roads can be calculated by adding up the cost of individual parts. The students have to build a network of paved roads in the Mud Town at the smallest cost.

Literature (Fellows, 1993) shows that some 5 -year-olds begin by putting the new swimming pool and their own home on the map first. Such personalization of the task can really boost the student activity, resulting in numerous suggestions from the students. Some are quick to recognize the problem while others need further guidance in finding the solution. 
Fellows (1993) reports that the students, who do not do well at traditional mathematical tasks did really well in this example, and vice-versa.

\section{Colouring the Map}

The teacher passes out a map, explaining that the students have to colour the countries in such way, that two countries, which share a border, have to be coloured with different colours. The teacher personalizes the problem by introducing the poor map colourer who is trying to make a living with just a few crayons. The students are faced with difficult questions, such as "Are two colours enough for this map?", "Will the colourer be able to complete the task with three colours?". There is no easy method of answering these questions but they are extremely valuable as they introduce an open problem, instead to close problems typically used in Maths lessons. The correct, i. e. the best solution is using the smallest number of colours. In order to achieve this, the students employ various strategies, observations and ideas. One that occurs frequently is colouring as many countries with just one colour before moving to the next one.

Picture 2: The Map of Europe (personal archive)

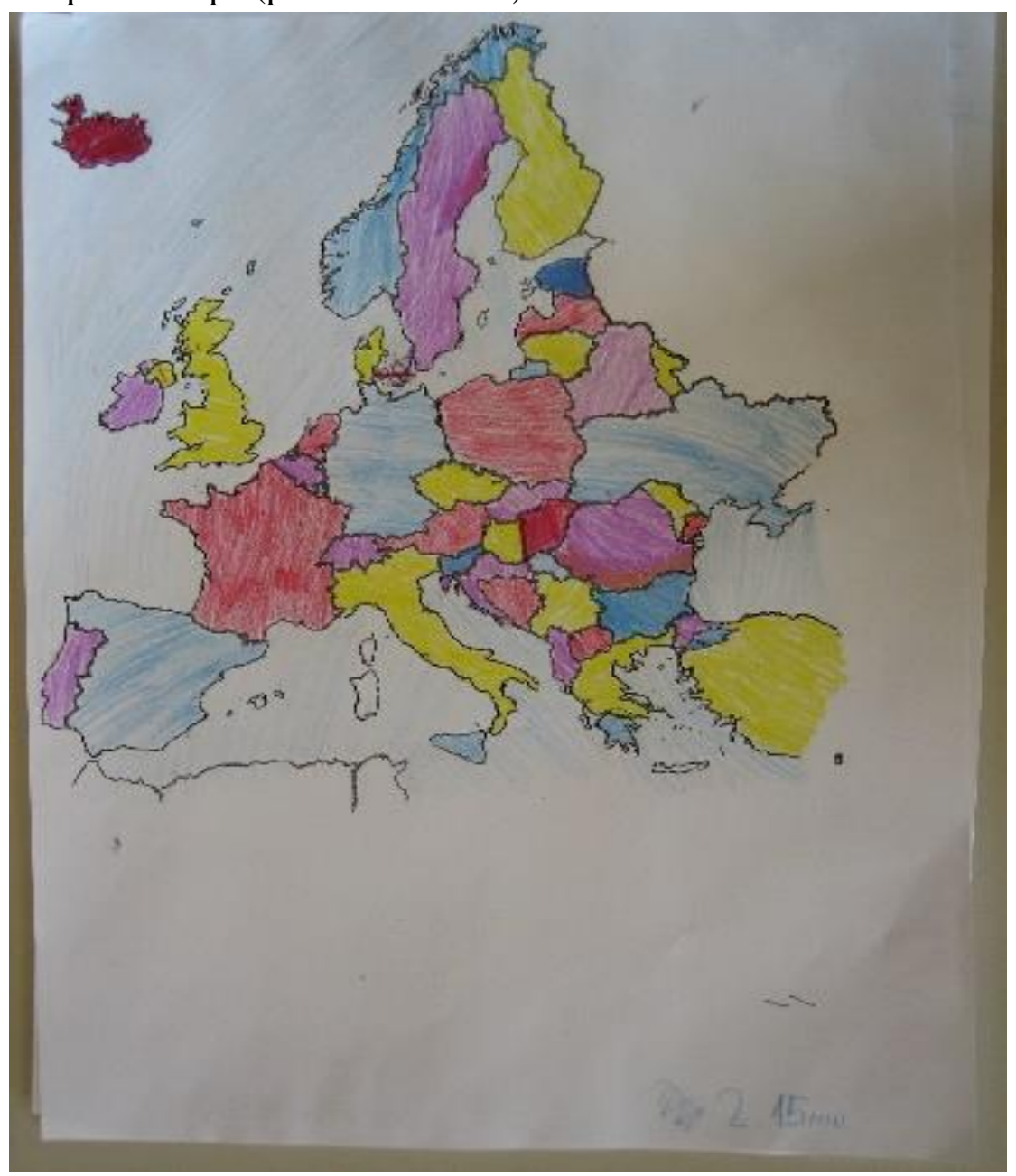




\section{Ice Cream Stands}

The task requires the students to find a minimum dominating set in a graph, i. e. find the smallest number of identical people, things, etc. This is regarded as a classic computational problem of computer science.

\section{Picture 3: Ice Cream Stands (personal archive)}

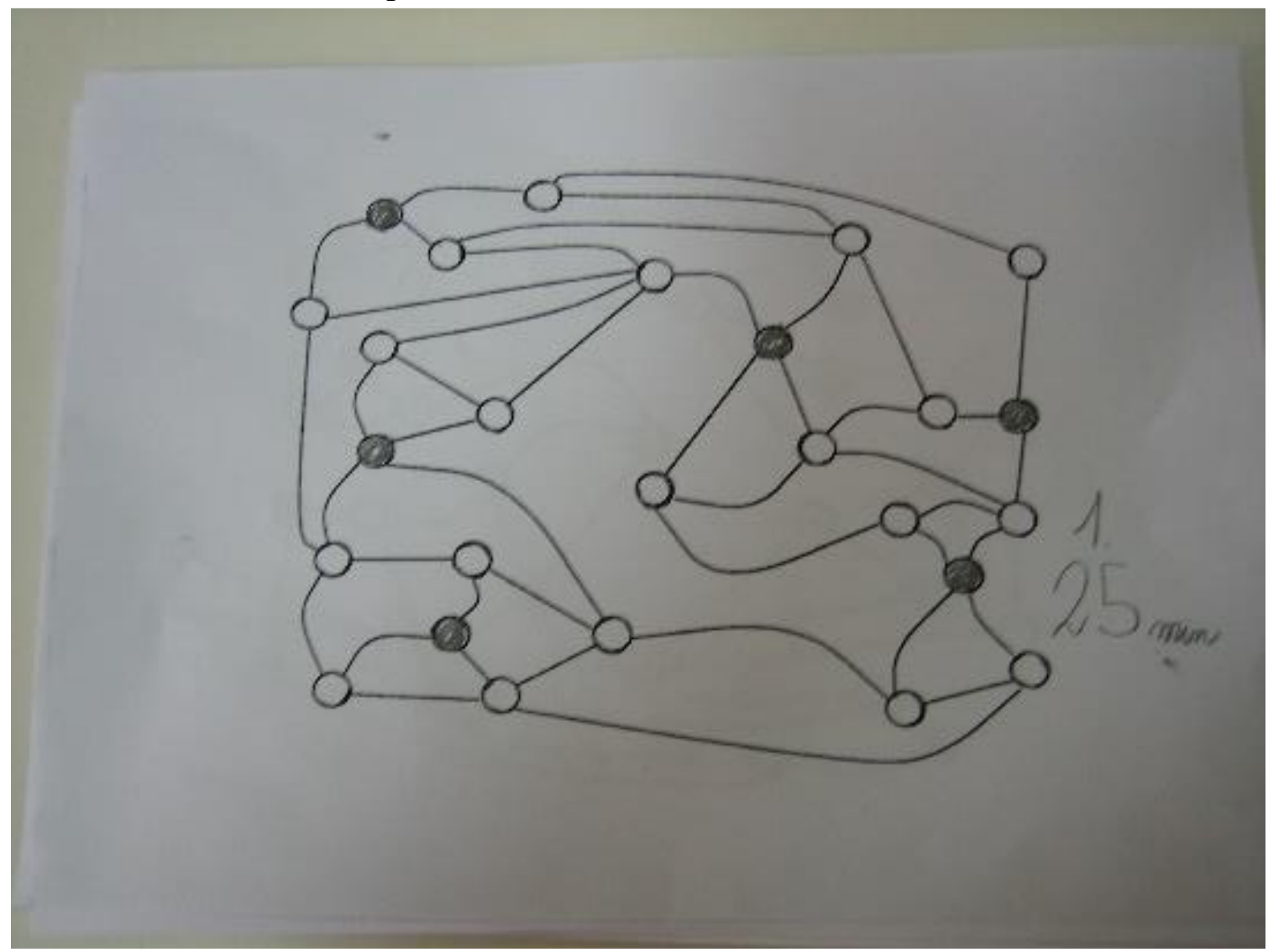

The students are presented with the story of a small town, called Sixtown. In order to prepare for summer, we wish to place an ice-cream stand on various locations in the town so that anyone could reach an ice cream stand by walking at most one block (i. e. one read). As we do not wish to spend too much, we want to place the smallest number of stands needed. The students are likely to offer many interesting observations and numerous strategies will always emerge when this problem is worked on.

\section{Conclusions}

Teaching Maths to younger students often requires introducing methods, which are not typically used in daily Maths lessons. The three activities we described are not typical mathematical tasks, however, they are related to mathematical and computer science. We have suggested doing the tasks in within-class groups, which requires the teacher to monitor the work if several particular groups at the same time. This requires more skill and better time management than typical frontal presentation of tasks to the whole class. 
The teacher can choose whether to work in homogenous or heterogeneous groups as not even two groups of students are alike. Therefore, the methodology has to be suited to particular students. The key aspect is finding the approach which will boost the activity of both high and low achieving students.

Our aim is to encourage the teachers to use such activities which support studentcantered classes which helps develop conceptual and procedural knowledge and allow them to step away from the typical mathematical tasks.

\section{References}

Adamič, M. (1996). Model sukcesivnega kombiniranja temeljnega in nivojskega pouka ter dosežki nivojskih skupin. Sodobna pedagogika, 47 (1-2). Ljubljana.
Fellows, M. R. (1993). Computer science and mathematics in the elementary schools, in N. D. Fisher, H. B. Keyens, and P. D. Wagreich, Ur., Mathematicians and Education Reform 1990-1991. Amer.Math. Society.

Hollifield, J. (1987). Ability grouping in elementary schools. Urbana, IL: ERIC Cleari

Slavin, Robert E. (1986). Ability grouping and student achievement in elementary schools: a bestevidence synthesis. Baltimore, MD: Center for Research on Elementary and Middle Schools.

Strmčnik, F. (2001). Didaktika: Osrednje teoretične teme. Razprava filozofske fakultete. Ljubljana: Znanstveni inštitut Filozofske fakultete.

Strmčnik. F. (2005). Učna diferenciacija in individualizacija $\mathrm{V}$ osnovni šoli. Vzgoja in izobraževanje, 36 (2/3), p. 5-9.

Žagar, D. (2003). Evalvacijska študija: Organizacija nivojskega pouka, stališča učencev, učiteljev in staršev do te oblike diferenciacije ter njeni učinki na učence (final report). Ljubljana: Filozofska fakulteta. 